University of Chicago Law School

Chicago Unbound

Journal Articles

Faculty Scholarship

2003

\title{
The Shaping of Chance: Actuarial Models and Criminal Profiling at the Turn of the Twenty-First Century
}

Bernard E. Harcourt

Follow this and additional works at: https://chicagounbound.uchicago.edu/journal_articles

Part of the Law Commons

\section{Recommended Citation}

Bernard E. Harcourt, "The Shaping of Chance: Actuarial Models and Criminal Profiling at the Turn of the Twenty-First Century," 70 University of Chicago Law Review 105 (2003).

This Article is brought to you for free and open access by the Faculty Scholarship at Chicago Unbound. It has been accepted for inclusion in Journal Articles by an authorized administrator of Chicago Unbound. For more information, please contact unbound@law.uchicago.edu. 


\section{FIGURE 1}

Sentenced Prisoners under Jurisdiction of State and Federal Correctional Authorities on December 31 (US, 1925-2000)

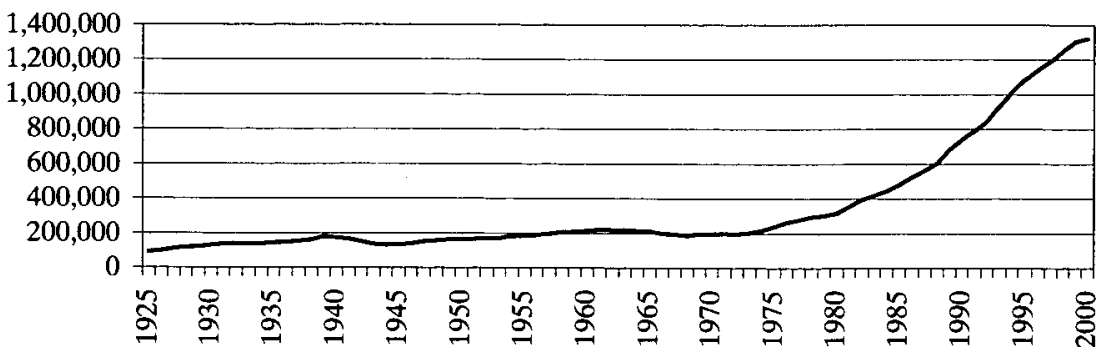

FIGURE 2

Adult Misdemeanor Arrests in New York City

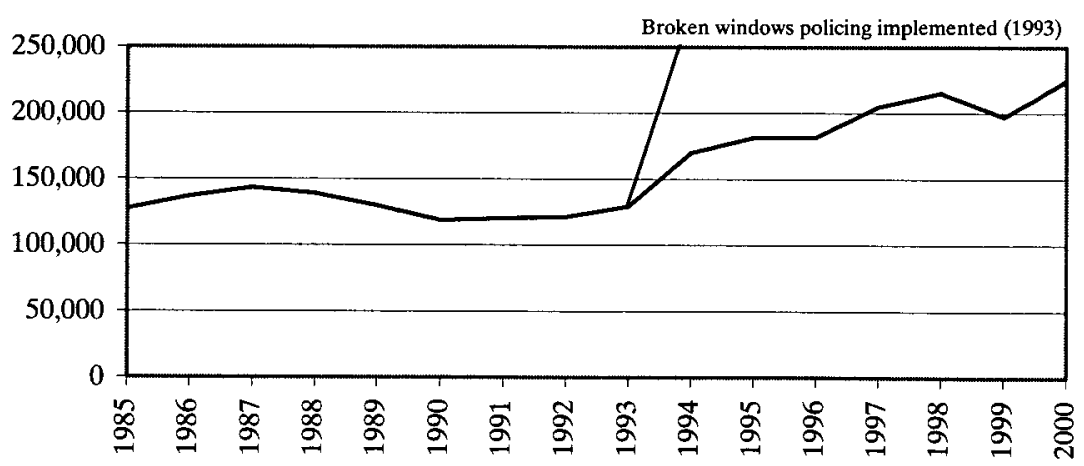

In addition, African-Americans began to represent an increasing proportion of the supervised population. Since 1926, the year the federal government began collecting data on correctional populations, the proportion of African-Americans newly admitted to state prisons has increased steadily from 23.1 percent to 45.8 percent in 1982 . It reached 51.8 percent in 1991, and stood at 47 percent in 1997 (see Figure 3). ${ }^{21}$ In 1997,

21 For statistics from 1926 to 1982, see Patrick A. Langan, Racism on Trial: New Evidence to Explain the Racial Composition of Prisons in the United States, 76 J Crim L \& Criminol 666, 666-67 (1985); for statistics from 1985 to 1989, see U.S. Bureau of Justice Statistics, Correctional Populations in the United States, 1995 Table 1.16 (June 1997); for statistics from 1990 to 1997, see U.S. Bureau of Justice Statistics, Correctional Populations in the United States, 1997, Table 1.20 (Nov 2000). 
9 percent of all adult African-Americans were under correctional supervision in this country, in contrast to 2 percent of European-Americans. ${ }^{22}$ The trend from 1984 to 1997 is reflected in Figure 4, which represents the percentage of adult populations in state and federal prisons and local jails by race and gender as a proportion of their representation in the general population.

FIGURE 3

Racial Distribution of Admissions to State Prisons, 1926-1997

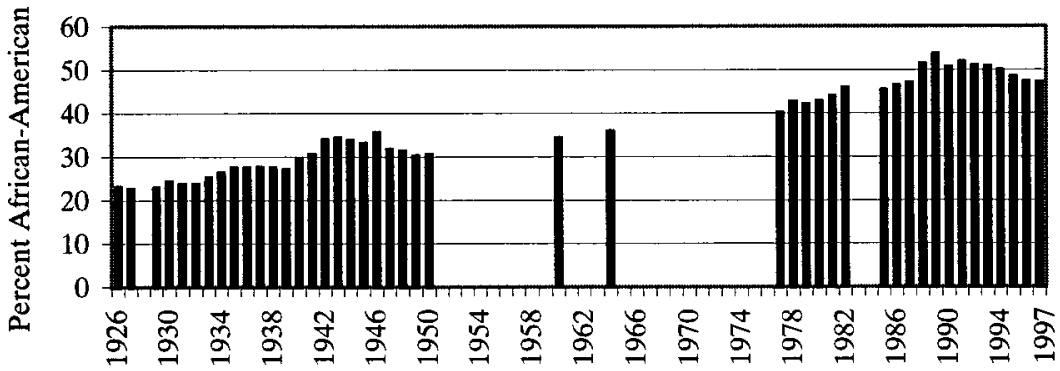

FIGURE 4

Percent of US Adult Population in State or Federal Prisons or in Local Jails, by Race and Gender, 1985-1997

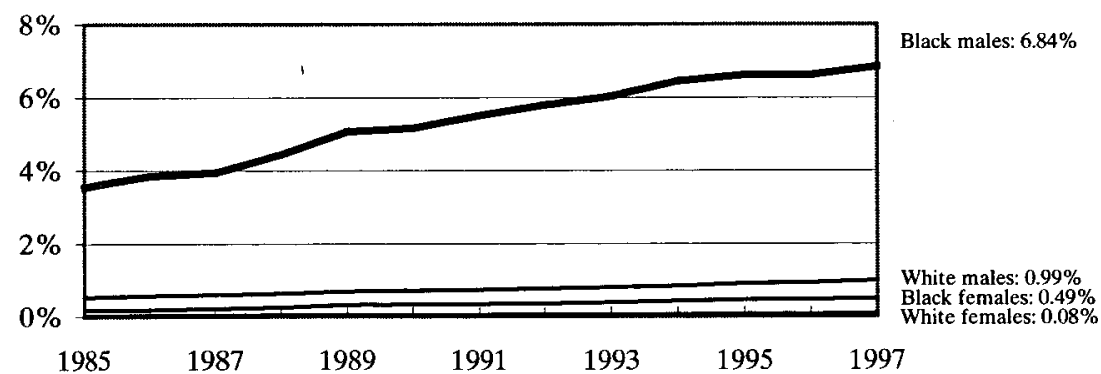

22 U.S. Bureau of Justice Statistics, Sourcebook of Criminal Justice Statistics Table 6.2 (cited in note 4).

23 U.S. Bureau of Justice Statistics, Correctional Populations in the United States, 1997, Figure 1 (cited in note 21). For excellent discussions of these trends, see Michael Tonry, Malign Neglect-Race, Crime, and Punishment in America 28-31, 56-68 (Oxford 1995). See also Justice Policy Institute, Cellblocks or Classrooms?: The Funding of Higher Education and Corrections and Its Impact on African American Men (2002), online at http://www.justicepolicy.org/coc1/corc.htm (visited Jan 5, 2003). 


\section{THE ACTUARIAL IN CRIMINAL LAW}

Scholars have offered different and contested interpretations of these trends. One intriguing line of research has attributed these shifts to a turn toward aggregation, risk analysis, and probabilistic thinking-in other words, toward an actuarial model of crime management -in the late twentieth century. In a 1991 article subtitled A Plea for Less Aggregation, Albert Alschuler emphasizes the increased use of aggregation in criminal sentencing. "Increased aggregation seems characteristic of current legal and social thought," Alschuler writes, "and what I have called 'the bottom-line collectivist-empirical mentality' now seems to threaten traditional concepts of individual worth and entitlement.." ${ }^{24}$ Alschuler places the emergence of aggregation in criminal law in the larger context of late twentieth-century developments, such as the procedural aggregation of civil claims through class actions and multi-district litigation, as well the emergence and recognition of group rights as a means of accomplishing larger social objectives. Lamenting the loss of individualization, Alschuler suggests that it has led to a new harm-based penology. "Judges determine the scope of legal rules, not by examining the circumstances of individual cases, but by speculating about the customary behavior of large groups," Alschuler explains. "We seem increasingly indifferent to individual cases and small numbers." "25 Malcolm Feeley and Jonathan Simon suggest that a new paradigm for the management of dangerous persons emerged in the late twentieth century, accompanied by a new language of penology. This new language replaces the earlier discourse of moral culpability, clinical diagnoses, intervention, treatment, and retributive judgment. It represents, in their words, an "actuarial language of probabilistic calculations and statistical distributions applied to populations. ${ }^{36}$ The language reflects a non-judgmental, managerial approach to criminal populations, which seeks to manage career criminals and minimize risk: "It seeks to regulate levels of deviance, not intervene or respond to individual deviants or social malformations.",

24 Albert W. Alschuler, The Failure of Sentencing Guidelines: A Plea for Less Aggregation, $58 \mathrm{U}$ Chi L Rev 901, 904 (1991).

25 Id at 904-05.

26 Malcolm M. Feeley and Jonathan Simon, The New Penology: Notes on the Emerging Strategy of Corrections and Its Implications, 30 Criminol 449, 450, 452 (1992). See also Jonathan Simon and Malcolm M. Feeley, True Crime: The New Penology and Public Discourse on Crime, in Thomas G. Blomberg and Stanley Cohen, eds, Punishment and Social Control: Essays in Honor of Sheldon L. Messinger 147, 163-69 (Aldine de Gruyter 1995). In his study of the California parole system, Jonathan Simon similarly offers an account of the development of parole along these lines-from its origins in the early twentieth century based on a model of work discipline, to a more clinical model in the 1950 s and 1960 s, to an actuarial or managerial model in the 1970s and 1980s. See Jonathan Simon, Poor Discipline: Parole and the Social Control of the Underclass, 1890-1990 (Chicago 1993).

27 See Feeley and Simon, 30 Criminol at 452 (cited in note 26). 
The new actuarial paradigm thesis met with some resistance and criticism. ${ }^{28}$ Nevertheless, the thesis has continued to weave its way into contemporary debates and literature, and there are today recurring sightings of the idea. ${ }^{29}$ Katherine Beckett, for example, in her insightful book Making Crime Pay, takes for granted the emergence of this new actuarial and managerial approach. She refers to "managerial criminology" as "technocratic, behaviorist, and 'realistic' in tone," and describes it as one in which "the language of probability and risk supercedes any interest in clinical diagnosis.", "These "risk assessments,"” Beckett writes, "are based not on knowledge of the individual case but on actuarial or probabilistic calculations. ${ }^{31}$ There is a sense in which the new actuarial paradigm thesis has begun to slip its way into contemporary discourse on crime and punishment. In part, this is because the concept of the actuarial connects with several strands of modern penalty - the emphasis on classification, risk assessment, preventative crime-control, and criminal profiling.

But the turn to probabilistic thinking pre-dates the twentieth century - in fact, it shaped the turn to the individualization of punishment in the early part of the twentieth century. Ian Hacking traces the history of the probabilistic revolution in The Taming of Chance, ${ }^{32}$ and demonstrates how the laws of probability had displaced in significant part the laws of necessity by the early twentieth century. The erosion of determinism - of conceptions of the laws of nature-during the nineteenth century did not give way to chaos or indeterminism, but instead to the laws of chance and probability - to the bell-shaped curve, the normal distribution. Paradoxically, the transition produced even greater control over the physical and social environment. As Hacking explains:

There is a seeming paradox: the more the indeterminism, the more the control. This is obvious in the physical sciences. Quantum physics takes for granted that nature is at bottom irreducibly stochastic. Precisely that discovery has immeasurably enhanced our ability to interfere with and alter the course of nature. A moment's reflection shows that a similar statement may be attempted in connection with people. The parallel was noticed quite early. Wilhelm Wundt, one of

28 See, for example, David Garland, Penal Modernism and Postmodernism, in Blomberg and Cohen, eds, Punishment and Social Control 181, 201 (cited in note 26) (suggesting that increased managerialism or actuarial analysis is in all likelihood attributable to the growth and maturation of the carceral system - a natural maturation process - rather than a shift in approaches).

29 See, for example, Stuart A. Scheingold, Constructing the New Political Criminology: Power, Authority, and the Post-Liberal State, 23 L \& Soc Inq 857, 866-69, 882-86 (1998); Katherine Beckett, Making Crime Pay: Law and Order in Contemporary American Politics 9-11 (Oxford 1997); David Shichor, Three Strikes as a Public Policy:The Convergence of the New Penology and the McDonaldization of Punishment, 43 Crime and Delinquency 470 (1997).

30 Beckett, Making Crime Pay at 9,103 (cited in note 29).

31 Id at 103.

32 Hacking, Taming of Chance (cited in note 3 ). 
the founding fathers of quantitative psychology, wrote as early as 1862: "It is statistics that first demonstrated that love follows psychological laws.",

Hacking relates statistical progress to a parallel phenomenon, namely the proliferation and publication of printed numbers beginning in the sixteenth and seventeenth centuries, but flourishing during and after the Napoleonic era. The proliferation of numbers helped create the categories of the normal, criminal, and pathological in the nineteenth century. As Jack Katz similarly has suggested, these categories took hold as a product of historical and political-institutional forces, rarely, if ever, as a result of causal social theory. ${ }^{34}$ But for our purposes here, the important point is that the paradigm shift took place during the eighteenth and nineteenth centuries, and was practically complete by the turn of the twentieth century. "The cardinal concept of the psychology of the Enlightenment had been, simply, human nature," Hacking explains. "By the end of the nineteenth century, it was being replaced by something different: normal people." ${ }^{35}$ Laws of chance had become autonomous - not irreducible, but autonomous in the sense that they could be used not only to predict but also to explain phenomena.

Most of these laws of chance were first observed, recorded, and publicized in the area of delinquence - crime, suicide, madness, and prostitution. Adolphe Quetelet, the great Belgian statistician, wrote as early as 1832 of the statistical regularities concerning crime, and he described the phenomenon as a "kind of budget for the scaffold, the galleys and the prisons, achieved by the French nation with greater regularity, without doubt, than the financial budget." ${ }^{36} \mathrm{Karl}$ Pearson, the famous statistician and eugenicist who assisted Charles Goring at the turn of the twentieth century, would summarize Goring's findings about "the English criminal as he really is": "on the average he is selected from the physically poorer and mentally feebler portion of the general population. The criminal," Pearson explained, "is not a random sample of the general population, either physically or mentally. He is rather a sample of the less fit moiety of it." ${ }^{37}$ Many years before that, Madame de Staël would observe that "there are cities in Italy where one can calculate exactly how many murders will

33 Id at 2.

34 Jack Katz, Seductions of Crime: Moral and Sensual Attractions in Doing Evil 43 (Basic 1988) ("The choice of the variables that are covered in the official data is structured by a multitude of historical and political-institutional forces; causal social theory has played little discernable part in this process.").

35 Hacking, Taming of Chance at 1 (cited in note 3).

36 Id at 105 .

37 Karl Pearson, Charles Goring and his Contributions to Criminology, in Charles Goring, The English Convict: A Statistical Study ix, xii-xiii (H.M. Stationery Office 1919). 
be committed from year to year." ${ }^{38}$ The first inroads into chance were made in the area of crime and punishment.

These laws of chance were precisely what grounded the new era of individualization at the turn of the twentieth century. The movement was premised on the new science of crime - on the idea that there are identifiable causes of crime that we could discover and study. The National Conference of 1909, which gave rise to the American Institute of Criminal Law and Criminology, was an outgrowth of the statistical discoveries emerging from positive criminology. Ernst Freund, Roscoe Pound, and their colleagues explained:

$[T]$ his truth opens up a vast field for re-examination. It means that we must study all the possible data that can be causes of crime, - the man's heredity, the man's physical and moral make-up, his emotional temperament, the surroundings of his youth, his present home, and other conditions, - all the influencing circumstances. And it means that the effect of different methods of treatment, old or new, for different kinds of men and of causes, must be studied, experimented and compared. Only in this way can accurate knowledge be reached, and new efficient measures be adopted.

Freund, Pound, and their colleagues, in fact, lamented the delay it had taken for American criminal jurisprudence to embrace the statistical paradigm.

All this has been going on in Europe for forty years past, and in limited fields in this country. All the branches of science that can help have been working, - anthropology, medicine, psychology, economics, sociology, philanthropy, penology. The law alone has abstained. The science of law is the one to be served by all this."

For Freund and Pound, then, the new science of crime provided the vital information necessary to determine why an individual committed a crime, and to find the right punishment for them.

The turn to individualization, no less than the later turn to incapacitation, rested on an actuarial aspiration. What changed markedly over the course of the twentieth century, then, was not the advent of actuarial thinking, of aggregation, and of risk analysis. The century witnessed instead the development and refinement of actuarial models. If one studies the more significant episodes in the development of the criminal law in the twentieth century-for example, the evolution of parole board deci-

38 Hacking, Taming of Chance at 41 (cited in note 3) (This, Mme de Staël concluded, demonstrates that "events which depend on a multitude of diverse combinations have a periodic recurrence, a fixed proportion, when the observations result from a large number of chances."). See generally Alix Deguise, Trois femmes: Le Monde de Madame de Charrière (Slatkine 1981).

39 Wigmore, et al, General Introduction at vii (cited in note 2) (emphasis added).

40 Id. 
sionmaking in the period 1900-1935, the growth of criminal profiling since the $1960 \mathrm{~s}$, and the development of sentencing guidelines in the 1980 s - it becomes apparent that actuarial models developed early and matured over the course of the century into the style of criminal law enforcement that we are familiar with today-an approach that relies increasingly on predictions of future criminality narrowly focused on crime severity and prior criminality. The fact that clinical models prevailed at first, during the early decades of the twentieth century, is due primarily to scarcity of resources and lack of knowledge, not to lack of will. Inadequate funding of criminal justice institutions delayed the development of actuarial predictive tools, but not for long. Functioning statistical models were realized and put in place relatively quickly -in some instances, by the early 1930s.

The development of parole in Illinois in the period from 1900 to 1935 , for instance, is a story of actuarial aspirations; clinical realities by default displaced by a multi-factored actuarial test, leading to a narrower and narrower actuarial model over time. The model gradually shifted from trying to find the most appropriate rehabilitative remedy to trying to predict success or failure on parole - something which can be far more easily operationalized. The formalization of parole guidelines had an important influence on the development of sentencing guidelines, which reflect clearly a political decision to abandon the individualized punishment model and instead to impose uniform, consistent, and proportional sentences. Sentencing guidelines have tended to further narrow the focus of the actuarial model on the severity of crime and prior criminal history. The development of criminal profiling in the mid-twentieth century reflects another effort to use a quasi-actuarial approach based on mixed statistical and clinical methods to predict criminal behavior. It reflects another tool that-like the later parole and the sentencing guidelines-is aimed narrowly at observable conduct and visible attributes associated with crime."

In the end, the net effect of the evolution of the actuarial in criminal law has been to train law enforcement increasingly on the narrow question of prior criminal history and severity of crime. The desire to predict criminality has had important consequences for the way we think about and engage in criminal law enforcement.

\section{CRIMINAL PROFILING: A THOUGHT EXPERIMENT}

This raises a number of questions, but in this Essay I would like to focus on one in particular: Is it possible that the refinement of actuarial

41 This is the topic of my current research. Preliminary findings will be presented in an article titled "From the Ne'er-Do-Well to the Drug-Courier Profile: The Actuarial in Criminal Law Enforcement" in a forthcoming issue of the Journal of Law and Contemporary Problems. 
models, in a world of scarce law enforcement resources, can do more than tame chance? Might it perhaps shape chance? Is it possible that allocating limited law enforcement resources on the basis of narrow predictive models might actually transform the social reality we live in? In this Part, I speculate that it might. If we identify a correlation between a group trait (gender, race, religion, education, wealth, criminal history, genes, etc.) and criminal activity, and then target our law enforcement on the basis of that trait, the paradoxical effect may be that the correlation itself gets reinforced over time. This is true whether the profiling is perceived as legitimate or not-whether it is a response to differential offending rates or whether it reflects purely malicious selective enforcement; whether we are merely allocating limited law enforcement resources in direct proportion to the amount of crime associated with that group trait or engaging in deliberate discrimination. In other words, if we target a high-crime subpopulation in relation to their contribution to crime rather than in relation to their representation in the general population, there will likely be a multiplier effect on their perceived contribution to crime over time. Using probabilities for purposes of crime prevention may be selfreinforcing.

This can be demonstrated with a simple computation, relying on a few basic assumptions about criminal profiling. For purposes here, I will use racial profiling as an illustration, and I will define racial profiling as the explicit or implicit use of race in law enforcement decisions such as, for example, the decision to stop and investigate a suspect, or the decision to police a specific neighborhood. Race is used explicitly when it is expressly referred to as one among other criteria, for instance when a police officer stops someone in part because she believes that members of that person's race are more likely to commit the crime under investigation. ${ }^{42}$ With the exception of anti-terrorism policing, this has become increasingly hard to establish. For that reason, I also include an implicit definition of racial profiling. Race is used implicitly when law enforcement is being targeted toward a racial group in greater proportion than that group's representation in the population - such as, for instance, when police officers stop-and-frisk young black men in proportion to their purported contribution to crime rather than their representation in the general population. This reflects a disparate impact prong of racial profiling.

42 For a definition of racial profiling along these lines, see Samuel R. Gross and Debra Livingston, Racial Profiling Under Attack, 102 Colum L Rev 1413, 1415 (2002):

As we use the term, 'racial profiling' occurs whenever a law enforcement officer questions, stops, arrests, searches, or otherwise investigates a person because the officer believes that members of that person's racial or ethnic group are more likely than the population at large to commit the sort of crime the officer is investigating.

This definition, as should be clear, includes the narrower case where an individual is stopped solely because of his or her race. In line with social reality, it adopts the broader definition. 
It is more controversial insofar as many commentators would not necessarily consider it racial profiling. The point of my analysis, though, is precisely to demonstrate that even this second type of racial profiling may be self-confirming.

When an accusation of racial profiling is made, the justification for disproportionate enforcement often rests on two premises. The first is that members of certain racial groups offend at a disproportionately higher rate than their representation in the general population. This premise is reflected, for instance, in the argument that the racial disproportionality in admissions to state prisons does not reflect racial discrimination, so much as differential involvement in crime (as measured principally by arrests). In articles in 1982 and 1993, Alfred Blumstein studied the racial disproportionality of the United States prison population, and essentially concluded that "the bulk of the disproportionality is a consequence of the differential involvement by blacks in the most serious kinds of crime like homicide and robbery." ${ }^{43}$ Blumstein's studies generated a tremendous amount of debate over the causes of racial disproportionality in prisons. Michael Tonry, in his book Malign Neglect, extensively reviews the literature, and concludes, with one important caveat, that "[f]rom every available data source, discounted to take account of their measurement and methodological limits, the evidence seems clear that the main reason that black incarceration rates are substantially higher than those for whites is that black crime rates for imprisonable crimes are substantially higher than those for whites." (The caveat is that, since 1980, the War on Drugs and other tough-on-crime measures deliberately contributed to the steady worsening of racial disparities in the justice system.) For present purposes, we need only observe that the justification for racial profiling often rests on the assumption of differential offending rates among different racial groups. ${ }^{45}$

43 Alfred Blumstein, Racial Disproportionality of U.S. Prison Populations Revisited, 64 U Colo L Rev 743, 759 (1993) (finding that overall approximately 76 percent of racial disproportionality in prisons in 1991 was attributable to differential arrest rates; also finding that the contribution of differential offending rates decreases with less serious crimes). See also Langan, $76 \mathrm{~J}$ Crim L \& Criminol at 682 (cited in note 21) (concluding that "even if racism exists, it might explain only a small part of the gap between the $11 \%$ black representation in the United States adult population and the now nearly $50 \%$ black representation among persons entering state prisons each year in the United States"); Alfred Blumstein, On the Racial Disproportionality of United States' Prison Populations, 73 J Crim L \& Criminol 1259, 1263-68 (1982) (finding that approximately 80 percent of the racial disproportions in prison in 1979 were attributable to differential arrest rates). For arguments challenging this proposition, especially the reliance on arrest statistics as evidence of offending, see Harris, Profiles in Injustice at 76-78 (cited in note 16) (arguing that arrests measure police activity, not offending). But see Tonry, Malign Neglect at 70-74 (cited in note 23) (arguing that arrests broadly reflect offending).

44 Tonry, Malign Neglect at 79 (cited in note 23). See also id at viii, 3, 50.

45 Those who oppose racial profiling, in fact, sometimes accept this first premise. Randall Kennedy, for instance, writes:

[T]here's no use pretending that blacks and whites commit crimes (or are victims of crime) in 
The second premise is that, if we discover disproportionate offending rates among a distinct group, it is only fair and efficient to target law enforcement resources roughly in relation to their disproportionate contribution to crime rather than to their representation in the general population. In other words, if African-Americans represent 25 percent of the general population, but 45 percent of the offending population, it is fair and efficient to expend about 45 percent of our law enforcement resources on African-American suspects or in African-American neighborhoods. This second premise is captured, for instance, in the argument that law enforcement officials engage in racial profiling "for reasons of simple efficiency. A policeman who concentrates a disproportionate amount of his limited time and resources on young black men is going to uncover far more crimes-and therefore be far more successful in his career-than one who biases his attention toward, say, middle-aged Asian women. ${ }^{46}$ To do otherwise, some argue, would make no sense:

A racial-profiling ban, under which police officers were required to stop and question suspects in precise proportion to their demographic representation (in what? the precinct population? the state population? the national population?) would lead to massive inefficiencies in police work. Which is to say, massive declines in the apprehension of criminals. ${ }^{47}$

Police officers who defend racial profiling often do so based on the disproportionate offending rates for certain crimes by certain members of minority groups. ${ }^{48}$ So, in New York City for instance, former police commissioner Howard Safir justified the disproportionate stops of AfricanAmericans and Hispanics by pointing to the disproportionate racial breakdown of crime, arguing that allocating resources along those lines is not discriminatory. "The ethnic breakdown of those stopped-and-frisked in the city as a whole," Safir emphasized, "corresponds closely with the ethnic breakdown of those committing crimes in the city." In the litigation concerning the New Jersey State Police and their practices of dispro-

exact proportion to their respective shares of the population. Statistics abundantly confirm that African Americans - and particularly young black men - commit a dramatically disproportionate share of street crime in the United States. This is a sociological fact, not a figment of the media's (or the police's) racist imagination.

Randall Kennedy, Suspect Policy, The New Republic 30, 32 (Sept 13,1999).

46 John Derbyshire, In Defense of Racial Profiling: Where is Our Common Sense?, 53 Natl Rev 38, 39 (Feb 19, 2001).

47 Id at 40.

48 See Dorothy E. Roberts, Foreword: Race, Vagueness, and the Social Meaning of OrderMaintenance Policing, 89 J Crim L \& Criminol 775,807 (1999) (critiquing police officers' views on the effectiveness of racial profiling).

49 See NYPD Response to the Draft Report of the United States Commission on Civil RightsPolice Practices and Civil Rights in New York City 13, online at http://www.ci.nyc.ny.us/ html/nypd/html/dclm/exsumm.html (visited Dec 2, 2002). 
portionately stopping black drivers on the New Jersey Turnpike between 1988 and 1991, the State of New Jersey's expert statistician attempted to prove that black drivers drive faster than whites, in an effort to justify the disproportionate number of law enforcement stops of black drivers. ${ }^{\text {so }}$ In fact, even some opponents of racial profiling accept this second premise: "Racial selectivity of this sort," Randall Kennedy writes, "can be defended on nonracist grounds and is, in fact, embraced by people who are by no means anti-black bigots and are not even cops."

A simple computation will show, however, that these two premises, if implemented in a world of limited law enforcement resources, may produce an unanticipated multiplier effect. Imagine a metropolitan area with one million inhabitants, where 25 percent of the population is AfricanAmerican (I will refer to this group as 'minority') and the other 75 percent is European-American, Asian-American, Hispanic, Native-American and other (I will refer to this group as 'majority'). Assume that the incarcerated population from the city consists of 5,000 persons (a rate of 500 per 100,000, which is consistent with current levels), that 45 percent of those incarcerated persons (or 2,250 persons) are minorities, and the other 55 percent $(2,750)$ are majorities. And assume that the incarceration rates reflect offending rates much more than intentional discriminationin other words, that minorities represent about 45 percent of offenders, majorities only 55 percent. What this means, naturally, is that minorities are offending at a higher rate as a percent of their population than are majorities. At time zero, here is the situation:

\begin{tabular}{|l|l|l|l|}
\hline Category & Total & Majority & Minority \\
\hline City Population & $1,000,000$ & $750,000(75 \%)$ & $250,000(25 \%)$ \\
\hline $\begin{array}{l}\text { Incarcerated } \\
\text { Population }\end{array}$ & 5,000 & $2,750(55 \%)$ & $2,250(45 \%)$ \\
\hline $\begin{array}{l}\text { Percent Incarcerated } \\
\text { by Group }\end{array}$ & $.5 \%$ & $.3667 \%$ & $.9 \%$ \\
\hline
\end{tabular}

50 See State of New Jersey v Soto, 324 NJ Super 66, 734 A2d 350, 354-55 (1996) (granting motions to suppress evidence on the ground of selective enforcement in violation of the equal protection clause). The court credited defense experts' findings. See id at 361 . These findings suggest absolute disparities of 32.7 percent (46.2 percent of stops were of blacks, 13.5 percent of drivers were black) and 22.1 percent (35.6 percent stops of blacks, 13.5 percent black drivers) based on stops at different intervals of the New Jersey Turnpike. Id at 353.

51 Kennedy, Suspect Policy, New Republic at 32 (cited in note 45). 
Now, assume that we decide to profile on the basis of offending rates by race - to allocate about 45 percent of our resources to minority suspects and 55 percent to majority suspects. Assume that we decide to stopand-frisk 100,000 persons, and that we are targeting offenses like drug or gun possession for which we do not have very reliable natural offending statistics. Since we do not have a reliable measure of offending, we use police data (arrest and resulting incarceration) as a proxy for offending rates. In year one, based on these assumptions, we stop 55 percent majorities and 45 percent minorities. Assuming that these populations are offending at the different rates, the new arrests and newly incarcerated population can be described at end of year one as follows:

\begin{tabular}{|l|l|l|l|}
\hline YEAR 1 & Total & Majority & Minority \\
\hline Stopped Population & 100,000 & $55,000(55 \%)$ & $45,000(45 \%)$ \\
\hline $\begin{array}{l}\text { Arrests and New } \\
\text { Admission Population }\end{array}$ & 607 & $\begin{array}{l}.3667 \% \text { of } 55,000 \\
\text { or } 202\end{array}$ & $\begin{array}{l}.9 \% \text { of } 45,000 \\
\text { or } 405\end{array}$ \\
\hline $\begin{array}{l}\text { Arrests and New } \\
\text { Admission Percentage }\end{array}$ & $100 \%$ & & \\
\hline
\end{tabular}

If we stop 55,000 majorities and they are offending at the assumed rate of offending for majorities of 0.3667 percent, then we are likely to find evidence of criminal activity with regard to 202 majorities $(0.3667$ percent of 55,000). If we stop 45,000 minorities and they are offending at the assumed rate of offending for minorities of 0.9 percent, then we are likely to find evidence of criminal activity with regard to 405 minorities ( 0.9 percent of 45,000$)$. At the end of the first year, we would have apprehended 607 persons through this policy of racial profiling of stop-andfrisks. We would be picking up, primarily, offenses such as possession of drugs, guns, or other contraband, drug dealing, probation violations, outstanding warrants, etc. We can imagine that a number of other individuals would be arrested during the period as a result of special investigations into homicides, rape, and other victim reported crimes. But focusing only on the stop-and-frisks, we would have 607 arrests and, at least temporarily, new admissions to jail (and later possibly prison).

Naturally, we are assuming here that the "hit rates" reflect perfectly the relative proportion of offenders in each racial group: that 0.37 percent of majorities and that 0.9 percent of minorities are offending in the targeted population. David Harris argues in Profiles in Injustice that the facts are otherwise. The growing data on racial profiling demonstrate that "[t]he rate at which officers uncover contraband in stops and searches is 
not higher for blacks than for whites, as most people believe," Harris emphasizes. "Contrary to what the 'rational' law enforcement justification for racial profiling would predict, the hit rate for drugs and weapons in police searches of African Americans is the same as or lower than the rate for whites." However, for purposes of this thought experiment, let us assume that the hit rate actually reflects the assumed higher rates of offending among minorities. ${ }^{53}$ Let us continue to take the racial profiling justification at face value.

Let us assume then that we continue each year to stop 100,000 persons, that we stop them using last year's arrests and new admissions rate as an accurate proxy of who is committing crimes - as an accurate reflection of offending-and that our hit rates continue to reflect the original assumed offending disparities. Recall that the arrest and new incarceration rate is being used as a proxy for offending differentials given that we do not have a reliable measure of natural offending rates for the targeted street crimes such as drug and gun possession. Notice here that we are aggressively pursuing a proportional law enforcement strategy, using last year's arrests and new admissions rather than the total incarcerated population, which would include the base levels of five-thousand persons plus the new admissions (less persons released during the year). Here is what happens in the next few years:

52 Harris, Profiles in Injustice at 13 (cited in note 16). Certainly, the experience in New York confirms the lower hit rates. According to New York State Attorney General Eliot Spitzer, the rate at which stop-and-frisks turned into arrests - in other words, the rate of stop-and-frisks that turned up evidence of criminal behavior - differs by race: during the period studied (Jan 1, 1998 through Mar 31, 1999), for every one stop that would lead to an arrest, the New York Police Department stopped 9.5 African-Americans, 8.8 Hispanics, and 7.9 European-Americans. The rate of stops to arrest for stops conducted by the Street Crimes Unit is even more disproportionate: 16.3 for AfricanAmericans, 14.5 for Hispanics, and 9.6 for European-Americans. Eliot Spitzer, The New York City Police Department's 'Stop \& Frisk' Practices: A Report to the People of the State of New York From The Office Of The Attorney General 111-12 (Office of the Attorney General of the State of New York 1999), online at http://www.oag.state.ny.us/press/reports/stop_frisk/stop_frisk.html (visited Dec 2, 2002).

53 Marginal reductions in hit rates in part may be an artifact of extremely disproportionate racial profiling (above and beyond any possible difference in offending rates). For instance, if the highway patrols in 1992 stopped and searched 70 to 80 percent African-American and Hispanic drivers on the Florida interstate highway, yet these groups represent only 5 percent of the drivers, there is bound to be disproportionately lower marginal hit rates for these groups. See Roberts, $89 \mathrm{~J} \mathrm{Crim} \mathrm{L}$ \& Criminol at 808-09 (cited in note 48 ). 


\begin{tabular}{|l|l|l|l|}
\hline YEAR 2 & Total & Majority & Minority \\
\hline Stopped Population & 100,000 & $33,280(33.28 \%)$ & $66,720(66.72 \%)$ \\
\hline $\begin{array}{l}\text { Arrests and New } \\
\text { Admission Population }\end{array}$ & 723 & $\begin{array}{l}.37 \% \text { of } 33,280 \\
\text { or } 123\end{array}$ & $\begin{array}{l}.9 \% \text { of } 66,720 \\
\text { or } 600\end{array}$ \\
\hline $\begin{array}{l}\text { Arrests and New } \\
\text { Admission Percentage }\end{array}$ & $100 \%$ & & \\
\hline
\end{tabular}

\begin{tabular}{|l|l|l|l|}
\hline YEAR 3 & Total & Majority & Minority \\
\hline Stopped Population & 100,000 & $17,000(17 \%)$ & $83,000(83 \%)$ \\
\hline $\begin{array}{l}\text { Arrests and New } \\
\text { Admission Population }\end{array}$ & 810 & $\begin{array}{l}.37 \% \text { of } 17,000 \\
\text { or } 63\end{array}$ & $\begin{array}{l}.9 \% \text { of } 83,000 \\
\text { or } 747\end{array}$ \\
\hline $\begin{array}{l}\text { Arrests and New } \\
\text { Admission Percentage }\end{array}$ & $100 \%$ & & \\
\hline
\end{tabular}

\begin{tabular}{|l|l|l|l|}
\hline YEAR 4 & Total & Majority & Minority \\
\hline Stopped Population & 100,000 & $7,780(7.78 \%)$ & $92,220(92.22 \%)$ \\
\hline $\begin{array}{l}\text { Arrests and New } \\
\text { Admission Population }\end{array}$ & 859 & $\begin{array}{l}.37 \% \text { of } 7,780 \\
\text { or } 29\end{array}$ & $\begin{array}{l}.9 \% \text { of } 92,220 \\
\text { or } 830\end{array}$ \\
\hline $\begin{array}{l}\text { Arrests and New } \\
\text { Admission Percentage }\end{array}$ & $100 \%$ & & \\
\hline
\end{tabular}

This thought experiment reveals two trends. First, the efficiency of our stops is increasing: Each year, we are arresting and at least temporarily incarcerating more individuals based on the same number of stops. Second, the racial composition of the arrests and new admissions is becoming increasingly disproportionate. In other words, racial profiling, assuming its premises and fixed law enforcement resources, may be selfconfirming: It likely aggravates over time the perceived correlation between race and crime. This could be called a compound or multiplier or ratchet effect of criminal profiling. Just like compounded interest, profil- 
ing may have an accelerator effect on disparities in the criminal justice system.

The important point of this thought experiment is that criminal profiling accentuates the purported correlation even assuming that the underlying assumptions are correct and that the practice is justifiable to some people. If the assumptions are wrong, naturally, criminal profiling will also be self-confirming. The same result-increased disproportionality of the racial balance of the incarcerated population-would occur if, for instance, all racial groups had the same offending rate, but we allocated slightly more of our law enforcement resources to minorities than their representation in the general population. Excellent scholarship underscores this point: If you spend more time looking for crime in a subgroup, you will find more crime there. ${ }^{54}$ My point here, though, is that the same type of effect will likely occur even on the assumption of differential offending - even if we accept fully the assumptions offered to justify racial profiling. This is going to be especially true for the more unreported types of crime such as drug possession or gun carrying.

A few caveats are in order. First, there may be a feedback effect working in the opposite direction, assuming that actors know something about profiling and respond rationally. In other words, other things may happen in response to the reallocation of crime fighting dollars. Persons in the targeted group may begin to offend less because they are being targeted. Persons in the non-targeted group may begin to offend more because of their perceived immunity. If so, there will possibly be a countereffect, and one would expect that the two distributions would begin to get closer to each other. As a result, there would be two competing forces at play: first, the ratchet effect; second, the feedback effect. The reason that I focus on the ratchet effect in the thought experiment is that it is logically entailed by criminal profiling. It is, in this sense, necessary and internal to profiling. In contrast, the feedback effect is an indirect effect. It is mediated by mentalities. It assumes dissemination of policing information and rationality on the part of criminal offenders-questionable assumptions that are, at the very least, likely to produce a more removed effect.

A second caveat is that there is likely to be an incapacitation effect as well. If we focus our stops so aggressively on minorities and incarcerate such high numbers of minorities, it is likely to reduce the number of potential minority offenders on the street-regardless of the rate of offend-

54 See, for example, id at 808-10. This is also the sense in which David Harris argues that racial profiling is a "self-fulfilling prophecy." Harris, Profiles in Injustice at 223-25 (cited in note 16). His argument is not that racial profiling is too effective. On the contrary, he argues that the evidence demonstrates it is ineffective and results in lower hit rates for minorities: "Racial profiling is neither an efficient nor an effective tool for fighting crime." Id at 79. His argument that racial profiling is nevertheless a self-fulfilling prophecy is, instead, that police will find crime wherever they look. If they spend more time in minority communities, they will find more crime there: "whom they catch depends on where they look." Id at 224. 
ing of the population. The incapacitation effect is going to exist whenever there are large scale arrests in a population.

A third caveat is that I have focused exclusively on one variablerace; police work rarely does, and practically never explicitly does anymore (outside international anti-terrorism policing). But the analysis would not differ if there were other variables. There would be the same ratchet effect for each variable, with different directions of increased disproportionality. There is no a priori reason to believe that the different directions of bias would cancel themselves out in any way-or would cancel out the effect on race.

A final caveat is that this is a simplified model that focuses aggressively on race/ethnicity and aggressively follows last year's arrest and newly incarcerated admission rates. Someone might respond that we should instead assume a fixed offending differential (say 45 versus 55 percent) and continue to enforce criminal law in that proportion regardless of the racial composition of the newly incarcerated. But first of all, how would we choose the original enforcement rate? For African-Americans, would we use the 23.1 percent from 1926 , the 45.8 percent from 1982, or the 51.8 percent from 1991 ? Which one of these reflects a more "natural" offending differential? In what sense would any of them be more reliable than the others? More reliable than last year's differential? How far back in history would we need to go to find the right differential? Also notice that the total incarcerated population and the racial imbalance of that population would be increasing each year. There would be a slower multiplier effect, but a multiplier effect nonetheless.

Using racial profiling as an illustration for criminal profiling is a double-edged sword. The advantage is that it facilitates engagement: We have all become extremely agile at thinking about and debating racial profiling, especially post 9/11. At the same time, however, we tend to draw a sharp distinction between racial profiling and other forms of criminal profiling. Race is unique in American practice and discourse, and it raises exceptional historical, political, and cultural dimensions. I am using racial profiling as an example, but what I have said about it should apply with equal force to other types of profiling-whether it is profiling of disorderly people (squeegee men and panhandlers), disaffected youth (trench coat mafia), domestic terrorists (young to middle-aged angry men), accounting defrauders (CEOs and CFOs), or tax evaders (the wealthy).

What I am suggesting is that criminal profiling generally, in a world of finite law enforcement resources, is likely to reshape perceived offender distributions along the specific trait that is being profiled, and this is likely to be the case whether the criminal profiling is viewed by some as a legitimate reflection of differential offending rates or instead the product of malicious selective enforcement and whether the underlying assumptions offered to justify criminal profiling are true or false. Criminal 
profiling is in all likelihood going to increase over time the observed difference in offending: If we target the wealthy for IRS audits at a rate proportional to their assumed higher contribution to tax evasion rather than to their representation in the general public, we likely will increase over time the perceived share of tax evasion committed by the wealthy, regardless of whether our assumptions are right or wrong. Similarly, if we target African-Americans for stop-and-frisks at a rate proportional to their assumed higher contribution to, say, crack cocaine possession or distribution rather than at a rate proportional to their representation in the general population, we will likely increase over time the perceived share of crack offenses committed by African-Americans, again regardless of whether our initial assumptions are right or wrong. Criminal profiling has a multiplier effect that, in all likelihood, gradually reinforces the perceived crime correlations-particularly where we do not have a good measure of natural offending rates.

\section{CONCLUSION}

Has the refinement of actuarial models in criminal law enforcement contributed to the observed criminal justice trends at the turn of the twenty-first century - to the sharp increase in incarceration and growing racial imbalance? Clearly, a combination of practices closely associated with criminal profiling have contributed to these national trends. These practices include drug interdiction programs at ports of entry and on interstate highways, order-maintenance crackdowns involving aggressive misdemeanor arrest policies, gun-oriented policing in urban areas, increased stop-and-frisk searches and police-civilian contacts. The investigatory search and seizure jurisprudence that has grown out of Terry $v$ Ohio $^{55}$ - especially cases such as Whren v United States ${ }^{36}$ where the Supreme Court upheld the use of a pretextual civil traffic violation as a basis for a stop-and-frisk procedure that was triggered by suspicion that the driver and passenger were engaged in drug trafficking" - has likely facilitated the emergence of these practices. ${ }^{s 8}$

A lot more research, though, would be necessary to begin to answer the question whether or to what extent the refinement of actuarial methods itself has contributed. It would be crucial to parse the data to explore

55392 US 1 (1968).

56517 US $806(1996)$

57 See id at 813-16.

58 See Terry, 392 US at 30-31 (holding that the "stop and frisk" procedures used by police did not violate the Fourth Amendment). See also United States v Villamonte-Marquez, 462 US 579 (1983) (otherwise valid warrantless boarding of vessel by customs officials not rendered illegal by ulterior motive of accompanying state police officer); United States $v$ Robinson, 414 US 218 (1973) (traffic violation stop not rendered illegal because it was a pretext for a drug search); Gustafson v Florida, 414 US 260 (1973) (same). 
which portion of the national trends are attributable to offender differentials versus disprortionate enforcement, as well as to measure any possible feedback and incapacitation effects. In exploring these questions, it will be important to focus not only on the numbers, but also on the political and social sensibilities that mark the turn of the century. Ian Hacking's research suggests that the proliferation of printed numbers alone was not enough to trigger the taming of chance. The probabilistic turn developed more in Western Europe (France and England), and far less in Eastern Europe (Prussia) because of different political sensibilities - the West being, crudely, more individualistic, atomistic, and libertarian; the East more community-oriented and collectivist. These sensibilities helped laws of chance in the West flourish, but inhibited their development in the East. The reason is that, in a world of collectivist sensibilities, the laws of regularity are more likely to be associated with culture than with individual behavior. In contrast, in a more atomistic world guided by Newtonian physics, social mathematics were more likely to flourish. ${ }^{59}$ Our research agenda, then, will need to focus not only on mathematical computations, but also on intellectual sensibilities at the turn of the twenty-first century.

Ultimately, we will also need to explore and weigh the value of police efficiency. The point of this Essay is that criminal profiling - and racial profiling, as an instance of criminal profiling - will have significant distributional consequences on incarceration rightly or wrongly. Many have argued wrongly, and if so, the matter is clear: The wrongful profiling of individuals has no offsetting benefit. It is inefficient, discriminatory, and injurious. But even if the underlying assumptions of profiling are right, there may nevertheless be adverse compounding effects. The targeting of subpopulations for purposes of policing efficiency does more than just improve efficiency. It may shape our perception of crime and our distribution of punishment. In the end, the decision to engage in criminal profiling is not just a matter of increased law enforcement efficiency. It involves a political and moral decision about the type of society that we are creating. There is a normative choice that needs to be made. The problem, if there is one, is certainly not the proliferation of printed numbers, nor the identification of statistical regularity. It is instead what we do with the information. 


\title{
Christopher St. German and the Law of Custom
}

\author{
R.H. Helmholz†
}

\section{INTRODUCTION}

Christopher St. German (ca. 1460-1540) has been described as the author of "the first critical discussion of the common law of any substance to be published." That is saying a great deal. So favorable an estimate must take it as a given that Bracton and Fortescue and Littleton were not critical enough of the common law to count. However, the description cannot possibly have meant 'critical' in the ordinary sense, as in the way that, say, Jeremy Bentham was critical of the common law. Bentham pointed to the many imperfections he saw in the common law and proposed schemes for their reform. ${ }^{2}$ St. German, by contrast, was no detractor of English law's merits. The description must instead have meant 'critical' in the sense of standing somewhat outside the common law and examining its meanings and its worth. In that sense of the word, St. German may have some claim to the title "first critic." He did purport to examine English law from outside. He did not merely extol its excellence or state its rules. And even if one concludes that he does not take the palm among impartial observers, his work deserves the attention of all students of the history of English common law - not least because he wrote on the dawn of development of the law from its medieval form to the form that emerged from its renaissance during the sixteenth and early seventeenth centuries. ${ }^{3}$

The book upon which St. German's reputation chiefly rests is known as Doctor and Student, although it was by no means his only learned work. Its main part appeared in 1528, and additions to it were School.

$\dagger$ Ruth Wyatt Rosenson Distinguished Service Professor, The University of Chicago Law

1 Eric W. Ives, St. German, Christopher, in A.W.B. Simpson, ed, Biographical Dictionary of the Common Law 458 (Butterworths 1984) (short biographical sketch).

2 Herbert L.A. Hart, Bentham, Jeremy, in Simpson, ed, Biographical Dictionary 44 (cited in note 1) (short biographical sketch) ("Bentham became, in John Stuart Mill's phrase, 'the greatest questioner of all things established' but his criticism never merely destructive, was accompanied by detailed plans for the reform of any branch of the law.").

3 See generally J.H. Baker, The Dark Age of English Legal History, 1500-1700, in Dafydd Jenkins, ed, Legal History Studies 19721 (Wales 1975) (describing legal thought in this era); Samuel E. Thorne, Tudor Social Transformation and Legal Change, 26 NYU L Rev 10, 10-11 (1951) (describing the transition from the medieval to the modern world). 
made in 1530 and 1531 . The whole has been many times republished, most recently and definitively in 1974 by the Selden Society. ${ }^{4}$ About the author we know less than we would like. He has remained a rather shadowy personality. We know he was a member of the Middle Temple, and that he gained a reputation among his contemporaries for uncommon learning in the Roman and canon laws as well as for his expertise in English common law. Bale described him as a man of quite extraordinary probity and piety-indeed Bale thought it not right to say his name without a certain reverence.' By common agreement, St. German was a man of good judgment in worldly matters. However, it was as a scholar, rather than as a man of the world, that he has become best known. Scholarship suited him.

Doctor and Student was written in the familiar if artificial form of a dialogue. On one side stood the Student of the English common law; on the other a Doctor of Theology. The ostensible occasion for their dialogue was the Doctor's desire to know more about the law of England - the common law. He had found so much of it written in French (he said) that he required the aid of an expert guide, and on that account he sought out his friend, the Student, who it turned out was quite willing to provide his aid. They proceeded to exchange information. The Doctor was not a mere interlocutor; he had learned something about English law, and he added what he knew from the ius commune. Sometimes he knew quite a bit of both. But the English common law held center stage throughout, and the Student was the principal informant.

What was the principal purpose of writing Doctor and Student? The answer to the question is not obvious. Legal historians have found it difficult to give a straightforward account of St. German's aims. Indeed they have discovered several purposes. First, St. German managed to convey a great deal of substantive law in the pages of his dialogue, and it was as a repository of learning that the work was most often used by lawyers in the centuries immediately after its publication. "Dr. \& St." was a common citation in the English reports of the sixteenth and seventeenth centuries. ${ }^{6}$ Second, the work anticipated the theme to which St. German would turn more aggressively in his later works: the conflict between the common law and the law of the church. On matters like tithes and the powers of Parliament, St. Ger-

4 T.F.T. Plucknett and J.L. Barton, eds, St. German's Doctor and Student (Selden Society 1974) ("Doctor and Student") (printed with the Latin version on one page and the English version on the facing page).

5 See John Bale, Index Britanniae Scriptorum 53-54 (Oxford 1902) (R.L. Poole, ed)

6 See, for example, Manby v Scott, 1 Mod 124, 126, 86 Eng Rep 781, 783 (Ex Ch 1663); Haughton v Wilson, 3 Keble 203, 204, 84 Eng Rep 677 (KB 1673); Green v Wilcoks, Cro Eliz 462, 78 Eng Rep 700 (KB 1596). 
man upheld the side of the temporal law.' Thomas More became his great opponent, and a natural one, for More was a clerically-minded layman-St. German was not. Third, the treatise explored the role of conscience and equity in law, both in the court of Chancery and the common law itself. ${ }^{8}$ To this discussion the Doctor added his own perspective, much of it taken from the ius commune. Finding a neutral place for equitable principles in the common law of contracts was a continuing (and difficult) preoccupation of the author.

It is true that these three purposes do appear, and even stand out, in Doctor and Student. It is no desire of mine to criticize or detract from their significance in understanding the work. It is my desire, however, to add a word about a fourth subject that has not been dealt with much in studies of St. German: the place of the law of custom in his work. This issue has received little scholarly attention. Perhaps custom's virtual eclipse as an independent source of law in our own day has kept us from recognizing just how prominent it was in the legal world of the sixteenth century and in the mind of St. German himself. But whatever the source of neglect, it is a subject that deserves attention if we are to make progress in understanding the nature of Doctor and Student and the contribution its author made to the formulation of the common law.

\section{THE LAW OF CUSTOM}

To appreciate the place of the law of custom in Doctor and Student requires starting with the medieval ius commune, the amalgam of Roman and canon law that long furnished the starting point for European legal education and for practice in the courts of the English church. The ius commune treated custom as a legitimate source of law. "Custom of long standing is rightly regarded as law," proclaimed a text in the Digest." "The usages of the people of God are to be taken as law in those matters where the sacred Scripture has established no certain rule," stated the Decretum Gratiani (ca. 1140), the first and ba-

7 He is described as a "publicist for Henry VIII's legal reformation of the English church" in Joan Lockwood O'Donovan, Theology of Law and Authority in the English Reformation 68 (Scholars 1991) (noting that his later work adopted the "more blatantly secularist program" of transferring the power of the clergy to the King).

8 See, for example, the treatment in W.S. Holdsworth, Sources and Literature of English Law 185-87 (Clarendon 1925) (noting that St. German pointed out parts of English law that "needed the help of equity").

9 See, for example, United States $v$ Rizzinelli, 182 F 675, 682 (D Idaho 1910) (finding an argument that custom supported the building of nonmining structures on mineral-rich land "without significance" in determining the validity of a regulation concerning such structures).

101 The Digest of Justinian 13 (Pennsylvania 1985) (Theodor Mommsen, Paul Krueger, and Alan Watson, eds) (translation of Digestum Justiniani 1.3.32). 
sic text of the medieval canon law." Custom was not simply a "background norm." For many purposes it was treated as binding law. However, it was also recognized that custom could be a source of harm to important social interests. An evil way of doing things was no less evil for having lasted a long time, and the ius commune treated it as a corruption of the law, not a legitimate source of law. ${ }^{12}$

How did one tell the difference? The subject admitted of disagreement about details among the commentators, but in general it is fair to describe the communis opinio as holding that before a custom could claim to be a source of law, it had first to be subjected to several tests. First, a custom had to satisfy requirements taken from the law of prescription; it had to be lengthy, open, and uninterrupted. Second, it must have been accepted by the community governed by it, and that community had to be of a sufficient size to sustain the observance. Third, a valid custom had to be consistent with both divine and natural law. And fourth, it was required to pass a test of reasonability.

Today, it may be thought that these requirements are questionbegging. What is meant by reasonability? How is one to know if the community accepts a custom? How large must the community be in any specific case? These inevitably require a policy choice made by a judge. But at the time St. German wrote, these tests were accepted as workable by the great majority of jurists. They often left room for argument in particular cases, but that much can be said of some legal standards in any age, and no one supposes they can be discarded simply because they cause uncertainty in outcomes.

The heart of the law thus involved first, establishing the existence of such a general usage as would satisfy the requirements of prescription and then, determining whether it also met more general requirements of reasonability and consistency with natural lawrequirements drawn from outside the positive law. One had to know what the purpose of a custom was and what its likely result would be, as well as determine whether it had been used for long enough by a large enough group. That was one of the merits of the jurists' approach: It clarified the workings of any custom and it tested them

11 Decretum Gratiani, Distinctio 11, canon 7.

12 See generally Udo Wolter, Die consuetudo im kanonischen Recht bis zum Ende des 13. Jahrhunderts, in Gerhard Dilcher, et al, Gewohnheitsrecht und Rechtsgewohnheiten im Mittelalter, 87, 104-14 (Duncker \& Humblot 1992); Peter Landau, Die Theorie des Gewohnheitsrechts im katholischen und evangelischen Kirchenrecht des 19. und 20. Jahrhunderts, 77 Zeitschrift der Savigny-Stiftung für Rechtsgeschichte, Kanonistische Abteilung 156, 158-68 (1991); John P. McIntyre, Customary Law in the Corpus iuris canonici (Mellen Research 1990); André Gouron, Coutume contre loi chez les premiers Glossateurs, in André Gouron and Albert Rigaudiere, eds, Renaissance du pouvoir legislatif et genèse de l'état 117 (Montpellier 1988); John Gilissen, La Coutume 24-33 (Brepols 1982); René Wehrlé, De la coutume dans le droit canonique 110-97 (Recueil Sirey 1928). 
against standards of reasonability. Indeed the method was not wholly different from what happens with judicial review of statutes in American courts.

It is particularly noteworthy that in the ius commune a custom could validly derogate from written law as well as supplement it. A community could establish a custom contra legem. This custom could thus contradict enactments in the positive law, typically those contained in the legislative commands of pope or emperor, as long as the custom met the tests just outlined. ${ }^{13}$ This was to become a controversial area of the law, and attempts were made to bring custom within the principles of sovereignty by supposing that law-givers had tacitly authorized customs they had not expressly reproved. Such attempts would lead ultimately to Austin's supposition that customs became binding law only when they were recognized as such by the sovereign. ${ }^{14}$ But this was a development in its infancy at the time St. German wrote. ${ }^{15}$ He took note that Parliament could change a rule of custom, ${ }^{16}$ but the doctrine that custom must have the approval, even the tacit approval, of Parliament was not part of his approach to the law.

\section{CUSTOM IN DOCTOR AND STUDENT}

It is the thesis of this Essay that the law of custom just outlined played a significant role in Doctor and Student, and that this role helps us to understand St. German's purpose in writing the treatise. ${ }^{17}$ Two initial points should be made. First, St. German knew something about the ius commune-perhaps not a great deal, but something! He cited the Summa Angelica, written by Angelo Carleto de Clavasio (d. 1495) and the Summa Rosella, written by Baptista de Salis (or Trovamala) (d. ca. 1494) with some frequency. ${ }^{18}$ These summae were alphabetically arranged guides to the law; they gave the general rules without the complex wrangling of the jurists and were not hard to use. He also cited a few of the great names in the field, notably Raymond

13 See glossa ordinaria ad X 1.4.11 s.v. rationabilis and legitime sit praescripta; glossa ordinaria ad Cod. 8.52(53).2 s.v. aut legem for the medieval understanding of the subject.

14 See John Austin, The Province of Jurisprudence Determined, Lecture I 30-32 (Noonday 1954) ("[B]efore [a custom] is adopted by the courts, and clothed with the legal sanction, it is merely a rule of positive morality.").

15 See Wehrlé, De la coutume at 273 (cited in note 12).

16 See Plucknett and Barton, eds, Doctor and Student at $48-49$ (cited in note 4) ("There are ... customs of the realm of England which have the force of law, and cannot be changed without parliament.").

17 There is an instructive parallel with St. German's use of the canon law to justify the equitable jurisdiction of the Chancellor. See Mark Beilby, The Profits of Expertise: The Rise of the Civil Lawyers and Chancery Equity, in Michael Hicks, ed, Profit, Piety and the Professions in Later Medieval England 72, 74 (Alan Sutton 1990).

18 See Index under "Summa Angelica" and "Summa Rosella" in Plucknett and Barton, eds, Doctor and Student at 346 (cited in note 4) (listing numerous cites to each). 
of Peñafort (d. 1275), the compiler of the Gregorian Decretals; Baldus de Ubaldis (d. 1400), the famous commentator on civil, canon, and feudal law; and Panormitanus (d. 1463), the greatest of the fifteenthcentury canonists. ${ }^{19} \mathrm{He}$ cannot have been truly familiar with their works, however. He cited each of these three men only once, and it is possible that he knew them only second hand, as by seeing them cited in one of the summae. St. German also cited, and more than once, the opinions of Jean Gerson (d. 1429), the famous Chancellor of the University of Paris, moral theologian, and knowledgeable critic of aspects of the medieval canon law. ${ }^{20} \mathrm{He}$ undoubtedly knew Gerson's works at first hand. But again, it was not the kind of knowledge acquired by an expert.

Second, custom as a source of law is one of the most often mentioned subjects in Doctor and Student. It recurs constantly. Custom was, for example, the third ground of the laws of England (the first two being the law of reason and the law of God). What St. German described as "general customs of old time used throughout all the realm, which have been accepted and approved by [the English Kings] and all their subjects" were for him an immediate source of English law. ${ }^{22}$ This was not an original idea, of course, among English lawyers. The medieval treatises known as Glanvill and Bracton had so characterized the English law in their descriptions and in their own titles. ${ }^{23}$ However, St. German returned to the theme of custom's place in English law again and again-so much so, that it was clearly more than one possible source of that law for him. It was, for example, "by the old custom of the realm" ${ }^{24}$ that eldest sons inherited to the exclusion of their younger siblings, that lords of land held by knight service had the right of wardship over the children of their tenants, and that livery of seisin was necessary to validate a feoffment of land. If a statute stated a rule, normally St. German described it as 'confirming' a rule

19 See id at 310 (reference to "Raymond"); id at 119 (citing Panormitanus); id at 321 (citing "Baldus de Perusio"). For a brief introduction to work of Raymond of Peñafort, see James A. Brundage, Medieval Canon Law 222-23 (Longman 1995) (biographical sketch). For Baldus de Ubaldis, see id at 207 (biographical sketch). For Panormitanus, see J.A. Clarence Smith, Medieval Law Teachers and Writers: Civilian and Canonist 94 (Ottawa 1975) (biographical sketch).

20 See Index under "Gerson, John" in Plucknett and Barton, eds, Doctor and Student at 344 (cited in note 4).

21 See Plucknett and Barton, eds, Doctor and Student at 45 ("The third ground of the law of England stands upon diverse general customs.") (spelling modernized).

22 Id (spelling modernized).

23 See Bracton De Legibus et Consuetudinibus Angliae (Bracton on the Laws and Customs of England) (Harvard 1968) (George Woodbine, ed, and S.E. Thorne, trans); The Treatise on the Laws and Customs of the Realm of England Commonly Called Glanvill (Nelson 1965) (G.D.G. Hall, trans).

24 Plucknett and Barton, eds, Doctor and Student at 46-47 (cited in note 4) (spelling modernized). 